\title{
Proton - Induced X - Ray Emission (Pixe) analysis of some sea food from Western Niger Delta,Nigeria
}

\author{
Agaja S.A. ${ }^{1}$ and Obiajunwa E.I. ${ }^{2 .}$ \\ Industrial Safety and Environmental Technology, \\ P.T.I., Effurun. \\ silaagaja@yahoo.com \\ Centre for Energy Research and Development, \\ O.A.U., lle-Ife.
}

\begin{abstract}
Periwinkles and crayfish are among the sea foods widely consumed by the people living in the coastal region of Nigeria. The systematic determination of trace - element concentration in periwinkles and Cray fish samples was done by the PIXE method using a $3.0 \mathrm{MeV}$ proton beam obtained from CERD (OAU, lle-Ife) ion beam analysis (IBA) facility. The following elements where detected and measured in all the samples $\mathrm{Na}, \mathrm{Ca}, \mathrm{Mg}, \mathrm{S}, \mathrm{Cl}, \mathrm{K}, \mathrm{Si}, \mathrm{Fe}, \mathrm{Cu}, \mathrm{Zn}, \mathrm{Br}, \mathrm{Sr}$, the concentration of the elements varied in the different samples, ranging from few ppm to few percent.
\end{abstract}

Key words: crayfish, periwinkles, PIXE, trace-elements

\section{INTRODUCTION}

Periwinkle Thais Lamelosa and crayfish As talus SP were among the popular sea foods consumed by the people living in the coastal region of Nigeria apart from being a major delicacy, they equally services as a source of economic empowerment for the people in the area. Although, periwinkles and crayfish are marine dwellers, they immigrate into brackish water systems during their post-larval stages, grow fast attain maturity in waters and lagoons. Their exposure to both marine and estuarine environment has all effects on the body burden of metal bioavailability from the natural as well as anthropogenic set up of the surroundings (Mohapatra et al, 2009) the interest on trace elements from the marine crustacean tissues arose from three areas of concern; nutritional, environmental and toxicological. Trace elements such as ( $\mathrm{Mg}, \mathrm{Na}, \mathrm{Ca}, \mathrm{Fe}, \mathrm{Zn}, \mathrm{Co}, \mathrm{K}$ ) are necessary at reasonable concentration for maintenance of human body and health trace elements such as ( $\mathrm{Pb}, \mathrm{Cd}, \mathrm{As}, \mathrm{V}, \mathrm{Hg})$ could pose a toxicological effect on human. Their tissue samples can also be used as a bio- indicator to assess bioavailability of contaminant concentrations in coastal water in environmental studies. This implies sea food is a significant pathway to trace metal exposure for people consuming them therefore, their analysis for trace elements is very essential.
Various studies have been reported on the trace elemental analysis of marine crustacean tissues for both biomedical and bioenvironmental using PIXE technique (Hota et al, 200l; Naga et al, 2005; Rautray et al, 2007 and Mohapatra et al, 2009). PIXE technique is known for its sensitivity, accuracy, precision simplicity of thick target preparation, ability to perform multielemental analysis of a large number of samples, sometimes quickly requiring very small amount of materials (Antoaneta et al, 2009).

\section{MATERIALS AND METHOD}

Sample Collection: The periwinkles and crayfish samples were bought from three riverside markets from Warri south, and Udu local government areas of Delta state Nigeria. The samples were put in clean white cellophane bags.

Sample preparation: The crayfish from the market were carefully selected, $100 \mathrm{~g}$ of the sample were taken from each of the samples bought from the three riverside markets visited, to form an aggregate sample of $300 \mathrm{~g}$ which was grounded in a clean augite mortal properly rinsed with de-ionize water the grounded Cray fish sample was packed into a clean sterilized $500 \mathrm{ml}$ plastic bottle 
The periwinkles bought from the market were carefully removed from their shell with the aid of a need-like stainless Metallic object. The periwinkles were thoroughly washed in de-ionized water to remove sand and other contaminant. They were put in a clean glass ware and carefully dried in a oven in the laboratory at a temperature of about $40^{\circ} \mathrm{C}$ to remove the moisture. The dried periwinkle was gently grinded in a clean dried augite mortal into a homogenous sample which was then packed into a sterilized clean $500 \mathrm{ml}$ plastic bottle.

The periwinkles shell were collected and thoroughly washed with de-ionized water to remove sand oil other dirt in them. They were gradually crushed and grounded into a coarse particle with a clean augite motor in the laboratory and packed into a sterilized plastic bottle.

Instrumentation: The PIXE experiments were performed using a $30 \mathrm{MeV}$ proton beam obtained from CERD ion beam analysis (IBA) facility. The facility is central on a NEC 5SDH 1.7 MV pelletron accelerator, equipped with a radio frequency charge exchange ion source. The ion source is equipped to provide proton and helium ions. The enlstation consist of an aluminum chamber of about $150 \mathrm{~cm}$ diameter and $180 \mathrm{~cm}$ height. It has four ports and a window. Port 1 at $165^{\circ}$ is for Rutherford Backscattering (RBS) detector, port 2 at $135^{\circ}$ is for PIXE detector, port 3 at $30^{\mathrm{O}}$ is for elastic recoil detection analysis (ERDA) detector, the window at $\mathrm{O}^{\mathrm{O}}$ is for observing the beam position and the size, which port 4 at $225^{\circ}$ is for PIGE. The end-station has a turbo pump and a variable beam collimator to regulate beam size, and an isolation value. Bovine liver standard (NIST 15 77a) was used for the determination of the $\mathrm{H}$-value which was subsequently used for analyzing the samples and to ensure the accuracy of the experimental procedure.

Analysis: The samples were analyzed with a beam spot of $4 \mathrm{~mm}$ in diameter and a low beam current of 3$6 \mathrm{nA}$. The irradiation was for about 10-20- minutes. A Canberra Si(Li) detector model ESTX 30-150, beryllium thickness of $25 \mathrm{~mm}$, with full width half maximum (FWHM) OF $150 \mathrm{eV}$ at $5.9 \mathrm{KeV}$, with the associated pulse processing electronics, and a Canberra Genie 2000 (3.1) MCA card interfaced to a PC were used for the x-ray data acquisition with respect to the beam director, the sample's normal was located at $\mathrm{O}^{\circ}$ and the $\mathrm{Si}(\mathrm{Li})$ detector at $45^{\circ}$. The PIXE set-up was calibrated using some pure element standards and NIST geological standard NBS278.
The PIXE data where analyzes with GUPIXWIN programmed. This provide a non-liner least square fitting of the spectrum with subsequent conversion of the fitted $x$-ray peak intensities into elemental concentrations utilizing fundamental parameter method for quantitative analysis . the relationship between characteristic X-ray yield $Y(Z)$ for an element of atomic number $Z$ and its concentration $C_{2}$ in a given target matrix.

$$
Y(Z)=H Y_{L}(Z) C_{Z} Q \in_{z} t_{z}
$$

Where $Y_{L}(Z)$ is the computed yield from the database steradam per unit concentration and per unit integrated beam charge.

$Q$ is the beam charge

$\epsilon_{2}$ is the intrinsic efficiency of the $\mathrm{Si}(\mathrm{Li})$ X-ray detector $t_{z}$ is the transmission of the $x$-rays through any absorber placed between detector and specimen.

$\mathrm{H}$ is the instrumental constant the product of the geometric solid angle of the $\mathrm{x}$-ray detector and any systematic normalization factor present in the charge integration system.

TECHNIQUE EVALUATION: For the checking of the reliability of the technique we measured the certified reference materials NBS 1577a (Bovine Liver) and IAEA-H-5 (Animal Bone) International Standards and comparison of the certified value with the measured value is shown in Tables 3.1 and 3.2. The measured values and the certified values are in good agreement this implies that the experimental method used in this study is reliable enough in analyzing the samples.

\section{RESULTS AND DISCUSSION}

Table 3.3 shows the various trace elements and their concentrations in the periwinkle tissue while, table 3.4 illustrates the trace elements and their concentrations in the cray fish while table 3.5 shows the trace elements and their concentration in the periwinkle shell.

Table 3.3 showed the concentrations of trace elements in the periwinkle tissue. The following elements have concentrations of over 1000ppm in the samples. $\mathrm{Na}, \mathrm{Mg}, \mathrm{Mn}, \mathrm{P}, \mathrm{S}, \mathrm{Cl}, \mathrm{K}, \mathrm{Ca}$ and $\mathrm{Fe}$. The following trace elements; $\mathrm{Ti}, \mathrm{Ni}, \mathrm{Cu}, \mathrm{Zn}, \mathrm{Br}, \mathrm{Rb}$, $\mathrm{Sr}$, have concentrations between $8.1 \pm 3.51$ and 169.1 
\pm 7.37 (ppm) in the periwinkle tissue. For the cray fish table 3.4 following elements concentrations were above 1000 ppm in the samples $\mathrm{Na}, \mathrm{Mg}, \mathrm{P}, \mathrm{S}, \mathrm{Cl}, \mathrm{K}$ and $\mathrm{Ca}$. while elements like $\mathrm{Al}, \mathrm{Si}, \mathrm{Ti}, \mathrm{Fe}, \mathrm{Ni}, \mathrm{Cu}, \mathrm{Zn}$, $\mathrm{Br}$ and $\mathrm{Sr}$ have concentrations between $5.3 \pm 2.46$ and $438.4 \pm 72.99$ (ppm). Table 3.5 showed the elements detected in the periwinkle shell $\mathrm{Ca}, \mathrm{Fe}$ and $\mathrm{Sr}$ are the elements with concentrations above 1000ppm. Calcium concentration was higher than $\mathrm{Fe}$ and $\mathrm{Sr}$ by a factor of 100 .

It could be observed from the results in tables 3.2 and 3.3 that some elements of nutritional value required for human body were detected and measured in the samples. Essential elements such as $\mathrm{Na}, \mathrm{K}, \mathrm{Ca}, \mathrm{Mn}, \mathrm{Fe}, \mathrm{Zn}, \mathrm{P}$ and $\mathrm{Mg}$ are required by human body and at reasonable concentration. However, presence of heavy metals like $\mathrm{Ni}, \mathrm{Mn}, \mathrm{Zn}$ and $\mathrm{Cu}$ are quite significant their concentration at higher level may become toxic to human body which can result in damage or reduced mental or central nervous functions, lower energy levels, and damage to blood composition, lungs kidneys, liver and other vital organs in the body (Seeley, et al 1998, Fox, S.I. 1999). Symptoms of Mn toxicity include dullness, weak muscles, headaches and insomnia while element like $\mathrm{Al}$ is not required because it perform no functions in human body and can be highly toxic.

Calcium found abundantly in the periwinkle and cray fish is very vital in human diet, it is important for the formation and maintenance of bones and also essential for blood clothing and muscles contraction (El-Shenawy 2004). Mg in the sample is required by human body as a micronutrient for bone formation functions. Presence of $\mathrm{K}$ in human transmission within the cells (Witney E, 2004). Iron is important for red blood cell formation, cognitive development and proper functioning of the immune system. A deficiency may lead to fatigue, low blood level and low blood pressure (Wardlaw, 2006). The recommended daily allowance (RDA) value is 26$40 \mathrm{mg}$ (Bakhru, 2002). Although high Fe concentration in humans can affect organs like liver, cardiovascular system and kidneys. Copper in human diet in appropriate concentrations helps in hormone synthesis and protein metabolism. Deficiency copper can lead to anaemia and low blood cell count as well as retarded growth daily intake of not more than $2 \mathrm{mg}$ is recommended any amount about this may become lethal (Bakhru, 2002)
The periwinkle shell is used in the animal feed industry as a source of minerals in poultry and animal ration. The shell is vey rich in essential minerals like $\mathrm{Ca}, \mathrm{Fe}$ and $\mathrm{Sr}$. also, useful for emulsion paint production, the construction industry uses it as an alternate chipping in concrete.

Table 3.1: NBS 1577a (BOVINE LIVER)

\begin{tabular}{|c|c|c|}
\hline Element & Concentration (ppm) & Certified values \\
\hline $\mathrm{Na}$ & $2428.6 \pm 476.01$ & 2430.0 \\
\hline $\mathrm{Mg}$ & $600.4 \pm 152.38$ & 600 \\
\hline $\mathrm{Al}$ & $338.5 \pm 99.96$ & 2.0 \\
\hline $\mathrm{Si}$ & $655.1 \pm 72.59$ & - \\
\hline $\mathrm{P}$ & $11123.5 \pm 75.64$ & 11100 \\
\hline $\mathrm{S}$ & $7797.3 \pm 55.36$ & 7800 \\
\hline $\mathrm{Cl}$ & $2881.8 \pm 33.43$ & 2800 \\
\hline $\mathrm{K}$ & $9913.6 \pm 33.71$ & 9960 \\
\hline $\mathrm{Ca}$ & $119.9 \pm 14.29$ & 120 \\
\hline $\mathrm{C} \mathrm{K}$ & $5.5 \pm 2.18$ & 194 \\
\hline $\mathrm{Mn}$ & $6.4 \pm 4.68$ & 9.9 \\
\hline $\mathrm{Fe}$ & $194.1 \pm 468$ & 158 \\
\hline $\mathrm{Cu}$ & $158 \pm 6.78$ & 12.3 \\
\hline $\mathrm{Zn}$ & $122.9 \pm 8.19$ & 9.0 \\
\hline $\mathrm{Br}$ & $9.0 \pm 2.95$ & 12.5 \\
\hline $\mathrm{Rb}$ & $12.5 \pm 5.53$ & \\
\hline
\end{tabular}

Table 3.2 IAEA-H-5(Animal Bone)

\begin{tabular}{|c|c|c|}
\hline Element & Concentration (ppm) & Certified values \\
\hline $\mathrm{P}$ & $102184.3 \pm 4669.82$ & 102000 \\
\hline $\mathrm{Cl}$ & $559.0 \pm 115.49$ & 550 \\
\hline $\mathrm{K}$ & $680.7 \pm 103.13$ & 680 \\
\hline $\mathrm{Ca}$ & $212070.8 \pm 254.18$ & 212000 \\
\hline $\mathrm{Fe}$ & $78.6 \pm 16.05$ & 79 \\
\hline $\mathrm{Zn}$ & $88.8 \pm 14.47$ & 89 \\
\hline $\mathrm{Sr}$ & $96.0 \pm 30.58$ & 96 \\
\hline
\end{tabular}


Table 3.3: Periwinkle tissue

\begin{tabular}{|c|c|}
\hline Element & Concentration (ppm) \\
\hline $\mathrm{Na}$ & $2704.4 \pm 683.33$ \\
\hline $\mathrm{Mg}$ & $14070.9 \pm 250.46$ \\
\hline $\mathrm{Mn}$ & $3323.2 \pm 71.55$ \\
\hline $\mathrm{S}$ & $8527.3 \pm 60.54$ \\
\hline $\mathrm{Cl}$ & $3686.0 \pm 37.60$ \\
\hline $\mathrm{K}$ & $3713.6 \pm 28.22$ \\
\hline $\mathrm{Ca}$ & $22363.4 \pm 38.02$ \\
\hline $\mathrm{Fe}$ & $1135.4 \pm 11.24$ \\
\hline $\mathrm{Ti}$ & $42.4 \pm 4.04$ \\
\hline $\mathrm{Ni}$ & $8.1 \pm 3.51$ \\
\hline $\mathrm{Cu}$ & $169.1 \pm 7.37$ \\
\hline $\mathrm{Zn}$ & $58.6 \pm 9.60$ \\
\hline $\mathrm{Br}$ & $19.3 \pm 8.30$ \\
\hline $\mathrm{Rb}$ & $19.3 \pm 8.30$ \\
\hline $\mathrm{Sr}$ & $69.2+15.76$ \\
\hline
\end{tabular}

\section{Table 3.4: Cray Fish}

\begin{tabular}{|c|c|}
\hline Element & Concentration (ppm) \\
\hline $\mathrm{Na}$ & $3889.1 \pm 571.15$ \\
\hline $\mathrm{Mg}$ & $1966.5 \pm 173.25$ \\
\hline $\mathrm{Al}$ & $419.8 \pm 104.53$ \\
\hline $\mathrm{Si}$ & $438.4 \pm 72.99$ \\
\hline $\mathrm{P}$ & $9693.6 \pm 78.52$ \\
\hline $\mathrm{S}$ & $8641.0 \pm 60.49$ \\
\hline $\mathrm{Cl}$ & $5590.4 \pm 42.49$ \\
\hline $\mathrm{K}$ & $12652.5 \pm 39.22$ \\
\hline $\mathrm{Ca}$ & $4272.9 \pm 25.64$ \\
\hline $\mathrm{Ti}$ & $11.0 \pm 3.23$ \\
\hline $\mathrm{Fe}$ & $37.2 \pm 2.97$ \\
\hline $\mathrm{Ni}$ & $5.3 \pm 2.46$ \\
\hline $\mathrm{Zn}$ & $52.5 \pm 6.71$ \\
\hline $\mathrm{Br}$ & $16.8 \pm 4.99$ \\
\hline $\mathrm{Sr}$ & $49.1 \pm 12.86$ \\
\hline $\mathrm{Sr}$ & $69.2 \pm 15.76$ \\
\hline
\end{tabular}

Table 3.5: Periwinkle Shell

\begin{tabular}{|c|c|}
\hline Element & Concentration (ppm) \\
\hline $\mathrm{Ca}$ & $428644.8 \pm 385.78$ \\
\hline $\mathrm{Ti}$ & $44.7 \pm 22.42$ \\
\hline $\mathrm{Mn}$ & $62.7 \pm 14.81$ \\
\hline $\mathrm{Fe}$ & $1448.6 \pm 28.10$ \\
\hline $\mathrm{Br}$ & $42.8 \pm 13.50$ \\
\hline $\mathrm{Sr}$ & $1344 \pm 65.60$ \\
\hline
\end{tabular}

\section{CONCLUSION:}

This study has provided trace elemental concentration information on periwinkle Thais Lamelosa and Cray fish Astacus Sp popular delicacy among the people living in the coastal areas of Nigeria. Also, a major source of income for many of the people. Some of the elements useful for humans body detected in the samples include: $\mathrm{Mg}, \mathrm{Na}, \mathrm{P}, \mathrm{S}$, $\mathrm{K}, \mathrm{Ca}, \mathrm{Fe}, \mathrm{Cu}$ and $\mathrm{Zn}$. An indicative of their nutritional value. Also the periwinkle shell contain high concentration of $\mathrm{Ca}, \mathrm{Fe}, \mathrm{Sr}$ and $\mathrm{Mn}$ which justifies the in animal and poultry feed ration formulation. The paints and construction industries also make use of the shell.

ACKNOWLEDGEMENTS: The authors are grateful to the authority of centre for Energy Research and Development, Obafemi Awolowo University, Ile-Ife for the priviledge to carry out the sample analysis in the centre.

\section{REFERENCES}

Mohapatra A, Rautray T.R., Patra A.K., Vijayan V (2009): Elemental Composition in mud crab Scylla serrate from Mahanadi estuary India: In situ irradiation analysis by external PIXE. Food and chemical toxicology, 47, p119-123.

Hota P.K., Vljaya V., Singh L.P. (2001) Application of x-ray spectroscopic analysis to human blood samples Ind. J. Phys. B75(4), P333-336

Naga Raju, Charles J, Bhuloka R, Sarita S (2005) Trace elemental analysis in Cancer-afflicted tissues of penis and testis by PIXE techniques. Nucl. Instru. Meth. Phys. Res. N 229, P457-464.

Raustray T.R., Vijayan V, Panigrahi S. (2007), Analysis of Indian Pigment Gallstones, Nucl. Instrum. Meth. Phys. Res. B 255 P409 - 415.

Serfor-Armah Y. Amoa C.M., Odamtten G.T., Opata N.S., Akhaho E.H.K. (2010) Determination of elemental and nutrient composition of water, clam mantle and shell of the volta clam (Galatea Paradoxa) Using chemistry 286 p39-45

Bakhru H.K. (2002): Vitamins that lead natural immunity for better health orient paperbacks, New Delhi, India

Warlaw G.M. Smith A (2006) Contemporary Nutrition. McGraw-Hill, New York, USA.

Witney E., Rolfes (2005) Understanding Nutrition. Thompson Learning Inc. Newyork

Fox S.I. (1999) Human Physiology. McGraw-Hill, New York, P731

Seeley R. R., Stephens T.D., Tate P. (1998): Anatomny and Physiology McGraw-Hill, New York, P1097. 